\title{
THE CUTICLES OF (?) THYLACOCEPHALAN ARTHROPOD FROM THE BASAL CHOTEČ EVENT (CHOTEČ FORMATION, EIFELIAN; BARRANDIAN AREA, CZECH REPUBLIC)
}

\author{
Michal Mergl
}

Center of Biology, Geosciences and Environmental Sciences, Faculty of Education, University of West Bohemia in Plzeň, Klatovská 51, 30619 Plzeň, Czech Republic; E-mail: Argyrotheca@seznam.cz

\begin{abstract}
Small fragments of phosphatic cuticle have been observed in dark limestone of the early Eifelian age (Choteč Formation) in the interval of the Basal Choteč Event. The cuticle is two-layered, primarily folded, with a chamber between outer and inner walls. Fragments likely represent small cuticle pieces from the margins of the carapace. The exterior of the cuticle is nearly smooth bearing irregular network of wrinkled polygons or shallow pits. Low conical mound-like to high thorn-like spines with annular structure extend from both outer and inner surface of cuticle. Wrinkled and folded bases of these spines indicate moderate flexibility of cuticle. Spines are hollow, the higher ones often with apical opening. The inner surface of carapace carries smaller spines or is nearly smooth. Chamber walls inside the carapace are with folds and other structures supporting stiffness of the cuticle. The internal walls of the cuticle are covered by polygonal bumps. These uniformly sized and shaped bumps are about $1 \mu \mathrm{m}$ sized and likely represents imprints of the epithelial cells adjoined to the basal membranous layer of endocuticle.

Biological affinity of cuticle fragments is unclear. They surely represent pieces of the arthropod carapace, the most probably a thylacocephalan. Associated fossils indicate a deeper marine environment. Bloom of prasinophytes, abundance of dacryoconarids and organophosphatic brachiopods, and striking rarity and diminutive size of other fauna indicate eutrophic conditions in a neritic sea, likely with hypoxic bottom water. Nectonic mode of life in open sea can be suggested for an animal bearing this cuticle.
\end{abstract}

Key words: Thylacocephalida, Phyllocarida, ultrastructure, epithelian moulds, Devonian

\section{INTRODUCTION}

Diverse phosphatic microfossils have been observed during a long-term investigation of organophosphatic brachiopods of the Central Bohemian Palaeozoic. Some microfossils can be easily classified to particular invertebrate group but others, generally rare to very rare, stay questionable. Typical problematic fossils are scarce remains of arthropod cuticles having phosphatic composition. While heavily sclerotised telsons or furcal rami can be referred to ceratiocaritids, extremely thin cuticle of these archeostracans and other non-related arthropods facilitates compaction, compression, abrasion, distortion or removal of selective parts (Collette \& Hagadorn 2010). The ultrastructure of three-dimensionally preserved fossil arthropod cuticles is poorly known although some modern investigations do exist (Broda \& Zatoń 2017, Braig et al. 2019).

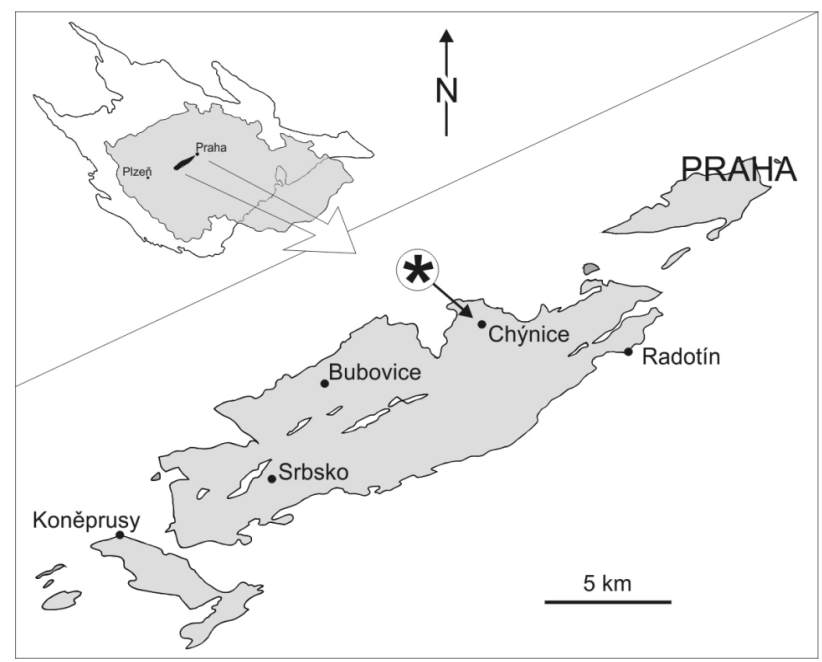

Figure 1. Sketch maps of the Czech Republic in the Bohemian Massif, the Devonian of the Barrandian area, and position of Na Škrábku Quarry locality. 
Rare fragments of cuticle that can be referred to arthropod phosphatic carapace have been yielded from the early Middle Devonian limestone of the Basal Choteč Event interval in the Barrandian area of the Czech Republic (Figure 1). Despite extreme fragmentation, observed cuticular fragments display complex and formerly unknown details. Therefore, although these cuticle fragments cannot be with certainty referred to any known taxon, their ultrastructure is thoroughly described.

\section{MATERIAL AND METHODS}

All cuticle fragments were yielded by dissolution of dark micritic limestone. Fragments are a by-product of investigation primarily focused on organophosphatic brachiopods, vertebrate microfossils, and conodonts. In total, more than $3.5 \mathrm{~kg}$ of rocks have been etched with $10 \%$ solution of acetic acid in pails for 3 to 5 days. Residues were not sieved to prevent secondary fragmentation. They were carefully and repeatedly washed by clean water in Petri dishes and dried. All fossils including cuticle fragments and other phosphatic microfossils were hand-picked from residues under the binocular lens OLYMPUS SZ51. Specimens were mounted on stabs with carbon adhesive plate and coated with gold. Material was studied using scanning electron microscope JSM-7401F in high vacuum.

\section{REPOSITORY}

All specimens are housed in the palaeontological collections of the Centre of Biology, Earth and Environmental Sciences in the Faculty of Education of the University of West Bohemia in Plzen (PCZCU), Czech Republic.

\section{GEOLOGICAL SETTING}

In the Central Bohemia, the early Middle Devonian (Eifelian) is represented by topmost part of the Daleje-Třebotov Formation (earliest Eifelian), the Choteč Formation (Eifelian) and the Srbsko Formation (latest Eifelian and Givetian) (Figure 2).
The lowermost Middle Devonian is represented by the topmost part of the Daleje-Třebotov Formation. The first occurrence of the index conodont Polygnathus costatus partitus falls within the uppermost part of the Trrebotov Limestone and, in the Koněprusy area, the uppermost Suchomasty Limestone (Klapper et al. 1978, Chlupáč et al. 1979). In the Prastav Quarry, former parastratotype, this level is situated $5 \mathrm{~m}$ below the Třebotov/Choteč limestones boundary (Berkyová 2009).

The overlaying Choteč Formation (Eifelian) is mainly represented by the Choteč Limestone (Svoboda \& Prantl 1948, Chlupáč 1957, 1959). The unit is built of grey to dark, organic-rich, well-washed peloidal grainstones and packestones (Berkyová 2009). In the lower part, the grey calcareous mudstone intercalations are frequent. These mudstone layers and associated thin dark limestone beds manifest the onset of the Basal Choteč Event (Chlupáč \& Kukal 1986, 1988), which is regarded as an important global transgressive event documented by a distinct facies and faunal change. The thickness of the Choteč Limestone varies between 40 and $60 \mathrm{~m}$ (Chlupáč 1998).

\section{LOCALITY}

All figured cuticle fragments come from the abandoned quarry Na Škrábku near Chýnice (Figure 1), from bed No. 12 (Plate I). The section at this quarry, representing the stratotype of the Choteč Formation, is situated at the foot of Škrábek Hill in the village of Choteč. The Třebotov and Choteč limestones crop in a steep slope of the quarry. The section was studied by number of authors (Svoboda \& Prantl 1948, Chlupáč 1959, Buggisch \& Mann 2004, Berkyová 2009, Berkyová et al. 2009, Koptíková 2011, Mergl \& Vodrážková 2012, Brocke et al. 2016). The detailed section of the Basal Choteč Event is figured in Brocke et al. (2016) and herein in Plate I.

The Choteč Limestone outcropped at the main wall of the quarry is striking by a set of several 1 to $10 \mathrm{~cm}$ thick beds of dark grey micritic limestone separated by dark mudstones (Plate I). This

Figure 2. Stratigraphy of the Devonian of the Barrandian area with position Na Škrábku Quarry locality (after Vaškaninová \& Kraft 2014, modified). 
Michal Mergl, The cuticles of (?) Thylacocephalan Arthropod from the Basal Choteč Event

Figure 2.

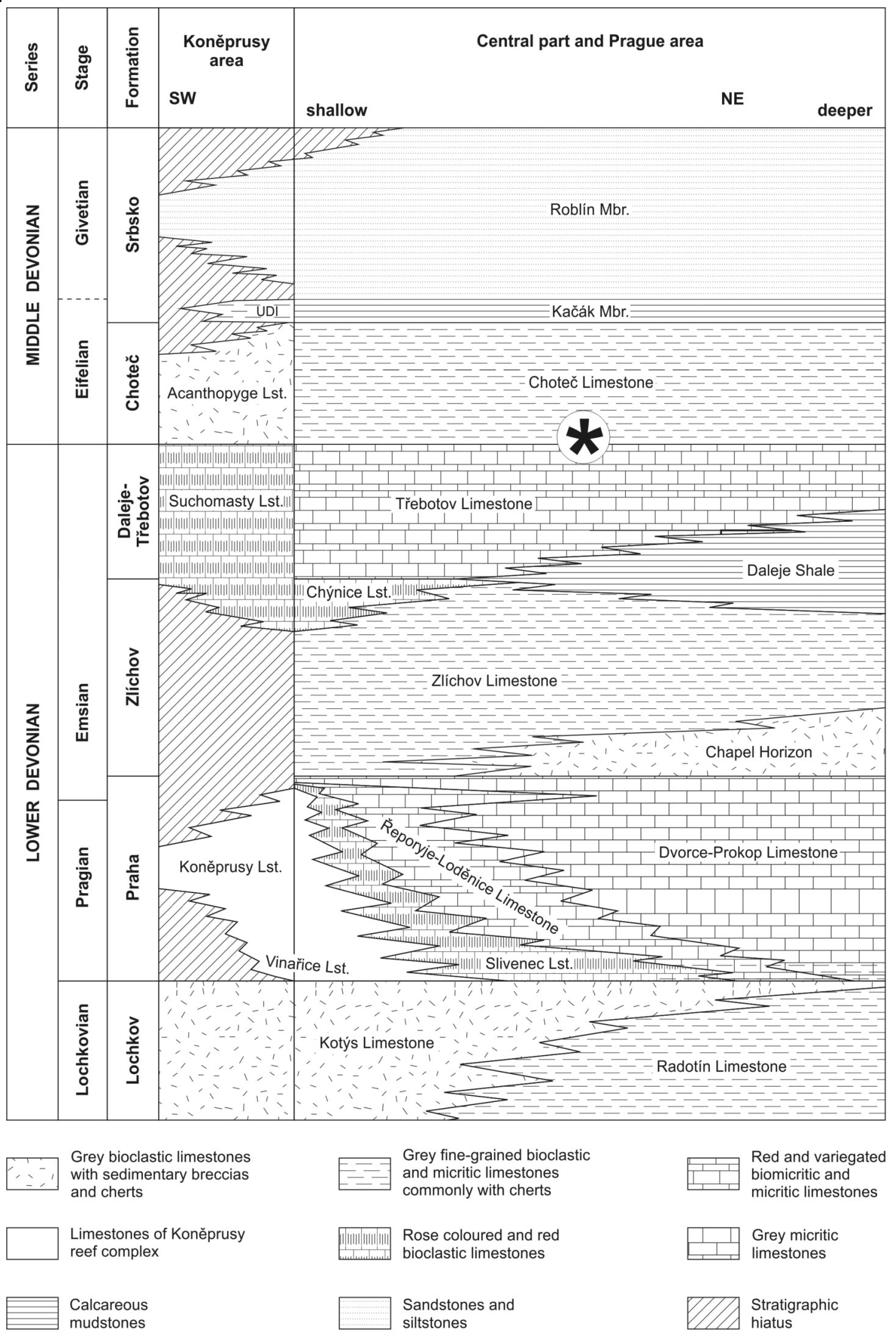



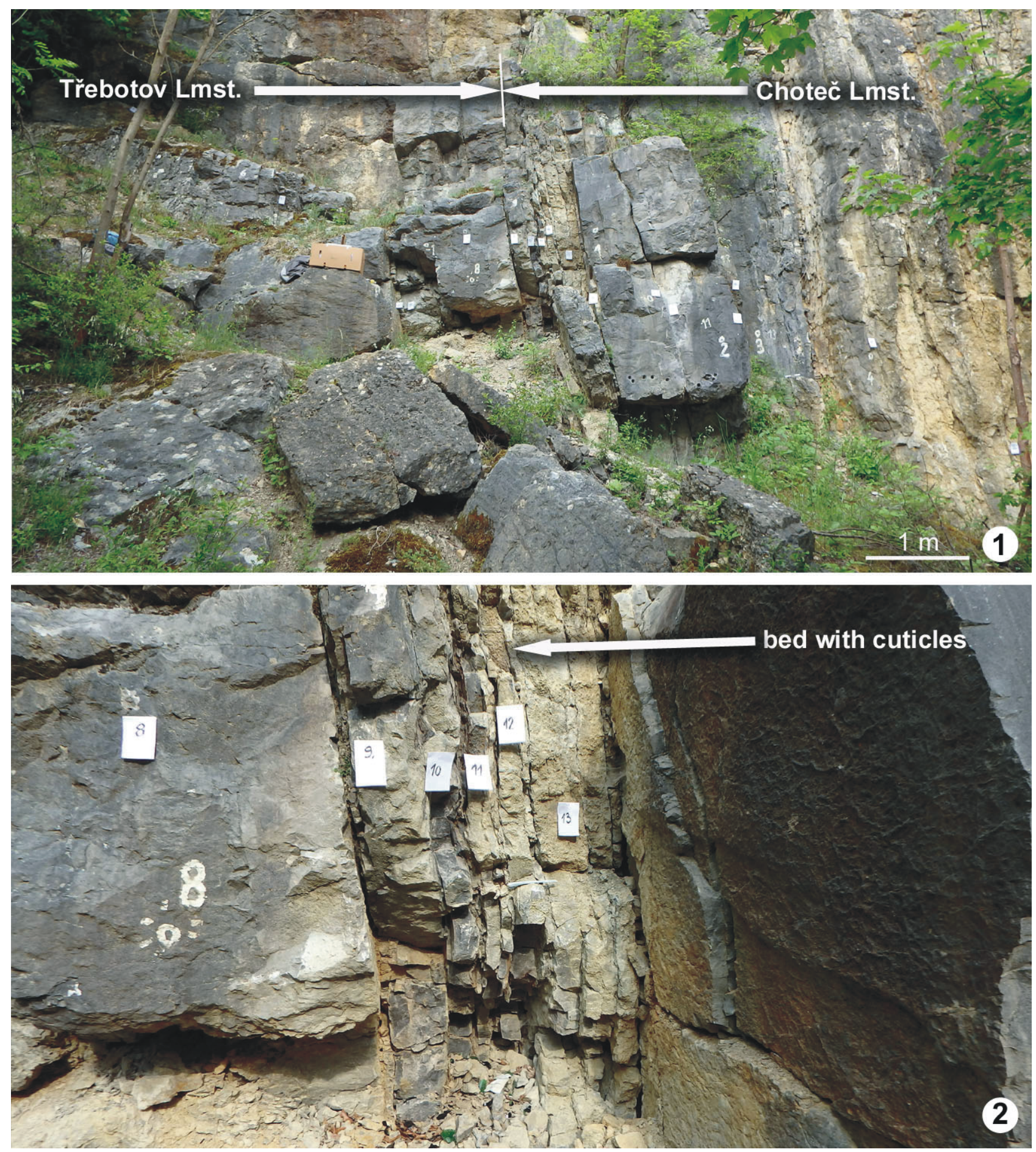

Plate I 1 - The wall of the Na Škrábku Quarry (in 2016) showing the upper part of the Třebotov Limestone and the lower part of the Choteč Limestone. The Basal Choteč Event interval is situated near the base of the Choteč Limestone and is characterised by thinner limestone beds inserted between massive limestone beds (in the middle of the photograph). $2-$ Close up to the Basal Choteč Event interval with limestone beds alternating with thin mudstone intercalations; numbers indicate particular limestone beds ( 8 - the topmost Třebotov Limestone, 9 to 13 - beds of the Basal Choteč Event). All cuticle remains came from a thin limestone bed (marked by arrow) at the top of bed No. 12 (sample No. 12top). The index goniatite Pinacites jugleri (Roemer, 1843) is preserved on large dark bedding plane (above the bed No. 13, at the same level as the base of the bed No. 1 in figure 1). 
approximately $0.7 \mathrm{~m}$ thick interval is confined to the lower part of the formation. Macrofossils are not abundant in limestone beds, and if present, they are typically small. According to Berkyová (2009) the occurrence of Polygnathus sp. aff. P. trigonicus Bischoff \& Ziegler, 1957 that was recorded $20 \mathrm{~cm}$ above the base of the Choteč Limestone can be indicative of the basal Polygnathus costatus Zone. Abundant dacryoconarids indicate the Nowakia sulcata Zone (Chlupáč 1998). Cuticular fragments are associated with small-sized and thin-shelled rhynchonelliform brachiopods $\mathrm{Ho}$ lynetes holynensis Havlíček \& Racheboeuf, 1979, Chlupacina longispina Havlíček \& Racheboeuf, 1979, Serrulatrypa incognita (Langenstrassen, 1972), Paraplicanoplia infima (Havlíček, 1977), and Chynistrophia foliola Havlíček, 1977 (Havlíček 1977, Havlíček \& Racheboeuf 1979). Characteristic constituents of the cephalopod fauna of the Choteč Limestone is a goniatite Pinacites jugleri (Roemer, 1843), the occurrence of which is proved on the bedding plane exposed immediately above interval of thin bedded limestones of the Basal Choteč Event (Plate I, fig. 2). Prasinophytes bloom has been documented from this interval (Brocke et al. 2016). Among phosphatic-shelled fossils within the interval of the Basal Choteč Event, the fragments of conulariid tests, byronid tubes, diverse and abundant lingulate brachiopods (Kosagittella, Prastavia, Bicarinatina, Paterula, Orbiculoidea, Lochkothele, Opatrilkiella, Opsiconidion; Mergl 2001, Mergl \& Vodrážková 2012), caudal spines of phyllocarids, myodocope ostracods, conodonts, and acanthodian scales were observed.

\section{MORPHOLOGY OF CUTICLE}

Phosphatic or phosphatised cuticle fragments are 1 to $1.8 \mathrm{~mm}$ long, and apart of one fragment (Plate II, fig. 1) all originate from peripheral parts of the carapace. Thickness of the cuticle is less than $5 \mu \mathrm{m}$ but is not uniform. The periphery of carapace is indicated by folding and two-layered structure of fragments, and in some fragments also by the presence of a distinct and internally reinforced rim (Plate II, fig. 13; Plate III, fig. 2) with tubular inner cavity. Uneven outline and surface of cuticular fragments confirm that they represent different parts of much larger carapace which, at least partly, was bordered by gently ventrally arched rim.
There are three types of superficial structure of the shield. The finely and evenly pitted structure covers a planar surface of some fragments (Plate II, figs 1,2). This presumably represents the outer surface of the carapace. One fragment shows a nearly smooth surface (Plate II, figs 3, 9) along the periphery and probably represents a different part of the carapace than those with pits and weakly convex margin. Three fragments with preserved peripheral rim bear irregular network of uneven polygons bordered by thin wrinkled ridges (Plate II, figs 7, 8, 12). However, although similar to much coarser structure of some thylacocephalids these ridges are likely of taphonomic origin. They resemble collapsing structures of the most external flexible cuticle (epicuticle?) on much tougher and thicker exocuticle below. The concavity bordering the peripheral rim (Plate II, fig. 13; Plate III, fig. 2) likely represents the inner side of the carapace. This surface is covered by dense system of irregular wrinkles bordering small polygons of uneven size, likely also of taphonomic origin. These polygons are about of half-size of polygons on peripheral rim. The concave slope of the rim (Plate II, fig. 13) bears weakly defined shallow subcircular depressions of about 5-7 $\mu \mathrm{m}$ in diameter. The depressions are regularly aligned alongside of a rim and continue into poorly defined alternating furrows and ridges running perpendicularly to rim on nearly planar inner surface of the carapace (Plate II, fig. 13; Plate III, fig. 2).

Spines of variable length, width and density are irregularly spaced on surface of the cuticle. Couples or clusters of small low spines are situated along the margin of the carapace (Plate II, fig. 4; Plate III, figs 1,2 ). These small spines are low, cone-shaped (Plate III, fig. 8) lacking an external opening and resting on weakly elevated surface of the cuticle. Slightly longer and wider spines often have almost always circular opening at the apex. Other spines may reach a remarkable length of nearly $300 \mu \mathrm{m}$ (Plate II, figs 13, 14). These largest spines usually have the apical opening (Plate II, fig. 13) but some show the blind end (Plate II, fig. 5). Some external openings are filled with sedimentary particles (Plate II, fig. 15). There is evidently a size continuum between low-conical to highconical spines. The spines have weak external annulation (Plate II, figs 5, 15) resembling telescopic retractable structure. The highest spine displays 


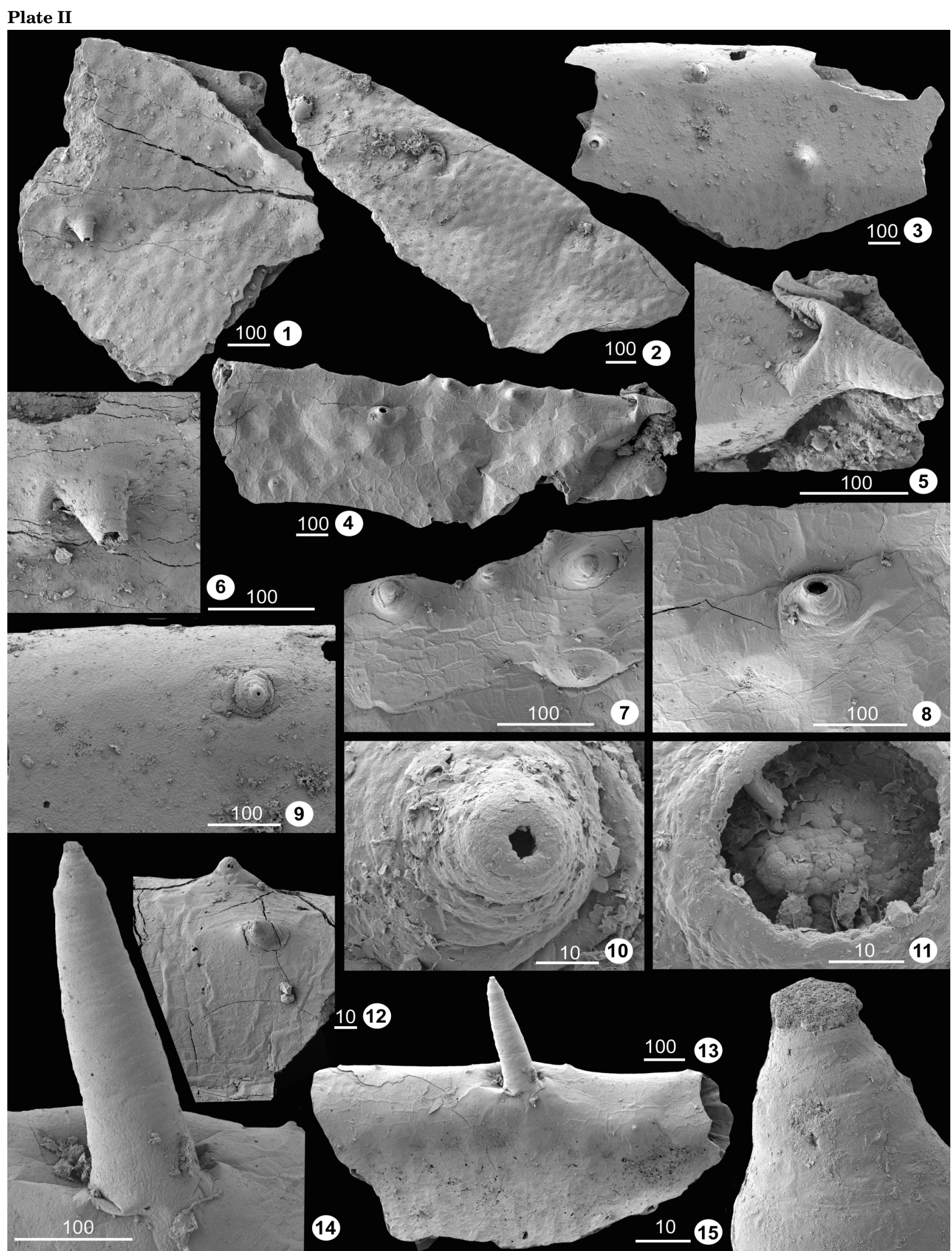


some 30 annuli (Plate II, fig. 14). If present, the apical opening is subcircular, 3 to $28 \mu \mathrm{m}$ in diameter, with rotund periphery (Plate II, figs 10, 11). The spines are oriented perpendicular to the surface of the cuticle. Most spines are present on a peripheral rim but some were observed both on outer and inner surfaces of the carapace. The function of spines is discussed below.

The mode of preservation of spines indicates high flexibility of the cuticle. In Plate II, fig. 5, there is the base of spine and adjacent cuticle which is double-folded and squeezed inside the spine; this corroborates vacant space inside the spine, at least in dead specimen with decayed tissues. The cavity devoid of cuticle is observable in all spines with the apical opening (Plate II, fig. 11). Flexibility of the cuticle is also confirmed by its deformation at the base is gently pressed into the cuticle (Plate II, fig. 14). Similar circular imprints around spines are perceptible in more fragments (Plate II, figs 2, 8).

Internal structures of carapace comprise folds or ribs forming structural reinforcement of cuticle (Plate III, figs. 3, 5-7). The reinforcement is well observable in walls of tubular cavity at peripheral rim. The cavity of more planar centripetal parts of the carapace is divided into chambers separated from each other by thin lamellae interconnecting inner and outer walls of carapace. Surface of folds, ribs and planar surface is covered by small polygonal bumps. These bumps are of approximately uniform size, $0.7-1.5 \mu \mathrm{m}$ in diameter. They are frequently but not obligatory pentagonal to hexagonal in outline, with convex surface and carved borders. Surface of each bump bears 30 to 50 small (100 to $300 \mathrm{~nm}$ wide) mineral spherulites.

\section{DISCUSSION}

\section{Biological affinity of cuticle fragments}

Described cuticle fragments presumably belong to single biological species. There are of the same morphological structural elements (uniform superficial ornamentation and shape of spines), mode of preservation, and occurrence in the same bed. However, the biological status is not clear. Twolayered structure of fragments, weak but conclusive traces of body segmentation, phosphatic composition of fragments, and presence of raised peripheral rim refer to the arthropod origin. However, originally phosphatic cuticle is rare among arthropods (Forchielli \& Pervesler 2013). Apart of generally small-sized Cambrian to Ordovician bradoriids and phosphatocopines, the only possible source of described cuticle fragments could be phyllocarids and thylacocephalans which were common and sufficiently large crustaceomorphs in the Lower Palaeozoic. There are only a few other Lower Palaeozoic arthropods (aglaspidids, some trilobites) with originally phosphatic cuticle (Forchielli \& Pervesler 2013) but their relationship with the studied cuticle fragments is not probable.

Plate II Scanning electron micrographs of exterior of arthropod cuticle fragments; all come from the lower part of the Choteč Formation, in the Basal Choteč Event interval, bed No. 12-top.

1, 6 - Fragment of cuticle with regular shallow pitting, likely the external surface of the carapace (?); note two-lamellar structure of cuticle, PCZCU 2396; 6 - detail of short hollow spine. 2 - Fragment of cuticle forming the margin of carapace with fine shallow pitting and two short spines, PCZCU 2402. 3, 9, 10, 11 - Fragment of cuticle; note smooth, likely internal surface of carapace with low short spines, PCZCU 2397; 10 - detail of spine showing external opening with unbroken periphery; 11 - detail of another low spine with large opening, likely unbroken periphery and cluster of convex bodies inside probably representing the imprints of tissue cells. 4, 5, 7, 8-Fragment of folded cuticle near the margin of carapace, with several short spines mostly without external opening, PCZCU 2398; 5 - detail of a long blind spine with annular structure; 7 - detail of these short blind spines; 8 - detail of single opened spine; note a flexibility of cuticle apparent near the base of a long spine indicated by polygonally wrinkled structure of the cuticle surface. 12 - Couple of blind low spines at the margin of carapace surrounded by distinctly wrinkled surface of the cuticle, PCZCU 2399. 13-15 - Fragment of cuticle at the margin of carapace, PCZCU 2400, with a single high spine (13), detail of erect spine (14) and detail of spine tip (15); note weak annulation of the spine $(13,14)$, flexible nature of cuticle apparent from weak gently pressed spine base into the cuticle (14), external opening of a spine filled by a cap of sediment $(14,15)$, wrinkles of cuticle surface $(13)$ and traces of segmentation marked by seven weakly defined depressions aligned near the junction of tubular marginal (top) and flattened parts (below) of the carapace. Scale bars are in micrometers. 

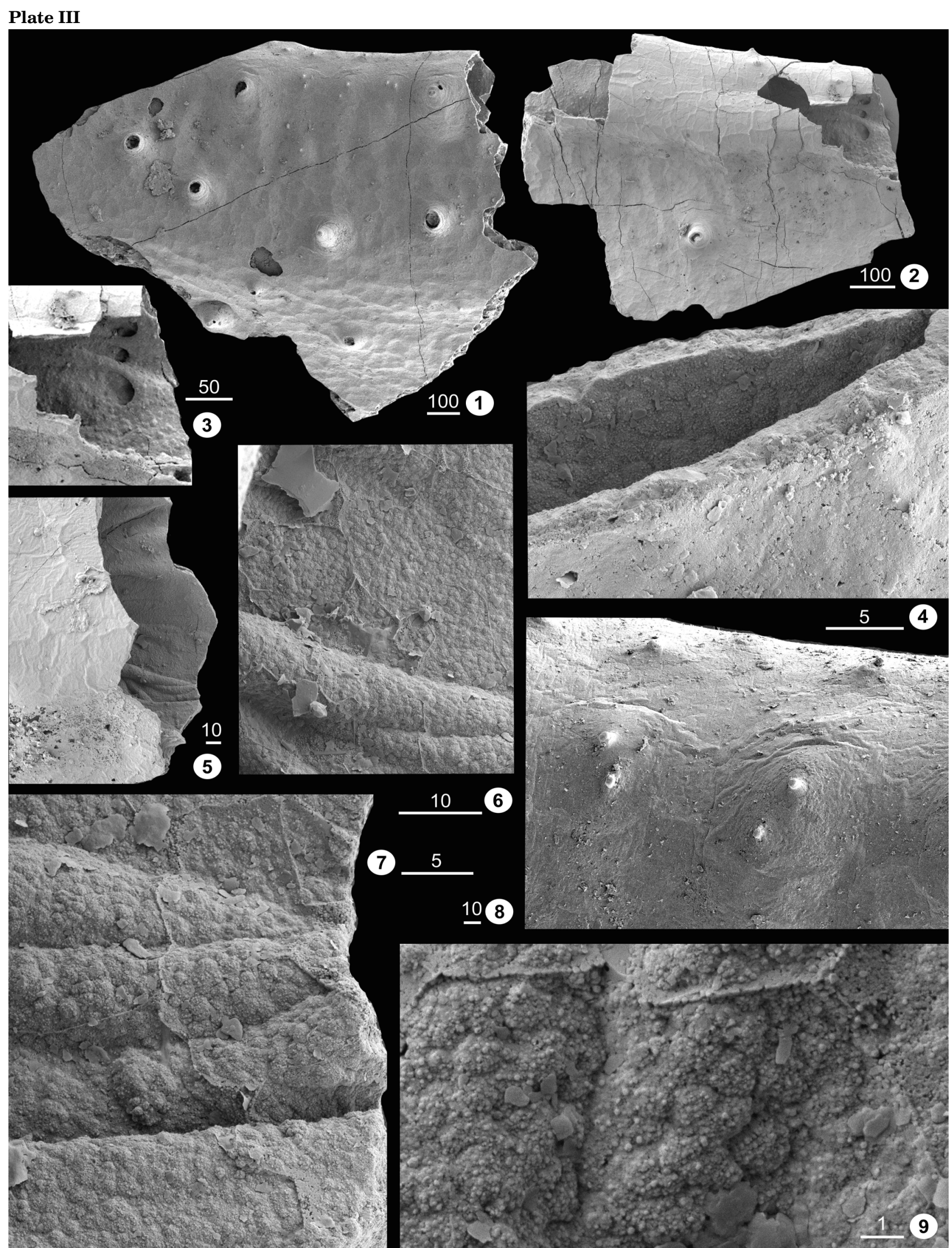
Phosphatic composition of the preserved cuticles excluded the arthropods with calcium carbonate mineralization. Eurypterids and other chelicerates can be ruled out, too, because they possess unmineralized cuticle with characteristic structure of nodes (e.g., Lamsdell et al. 2015a, 2015b; Briggs et al. 2018). The size of fragments and weak convexity of rim observed on these fragments indicate carapace size in a centimetre rank. Two-layered periphery of fragments evidences on uni- or bivalved carapace encapsulated, at least in part, the trunk of animal. Consequently, two groups of Middle Palaeozoic arthropods are convenient candidates to owner of described cuticle fragments: the thylacocephalans or the phyllocarid crustaceans.

Diagnostic features of thylacocephalans were summarized by Pinna et al. (1982), Vannier et al. (2006), and more recently by Braig et al. (2019). Very reduced trunk of thylacocephalans with short segments observed in the Late Jurassic Falcatacaris bastelbergeri Braig, Haug, Schädel \& Haug, 2019 may be in agreement with densely arranged parallel grooves and ribs observed on the internal surface of the Bohemian cuticle fragments. These serial structures likely reflect the original trunk segmentation. If these cuticle fragments came from the ventrocaudal part of the carapace it could support the thylacocephalan origin of the Bohemian cuticle fragments.

However, there are significant differences. The Bohemian cuticle fragments lack characteristic external surface structures observed in many thylacocephalans (Vannier et al. 2006, Broda \& Zatoń 2017). Spines of variable size and shape observed in the Bohemia fragments are unknown in other thylacocephalans. However, thylacocephalans Protozoea hilgendorfi Dames, 1886 and Pseu- derichthus cretaceus Dames, 1886, both from the Cretaceous of Lebanon, have carapace structures with "pits" which interpreted as ring-like tubercles are believed to be bases of spines (Schram et al. 1999). Schram et al. (1999) agreed with suggestion of Secretan (1985) that these structures represent sensory organs composed of a hemisphaerical structure covering carapace cuticle with a small pore as an opening to the outside. Schram et al. (1999) also discussed the type of these organs. They assumed, that these rounded structures represent some kind of pressure-receptor instead of photophores as Rolfe (1985) suggested earlier. The small spines observed in the Bohemian cuticle are blind and covered by a thin cuticle; the large spines have externally opened pore of various diameter. The various sizes of pores contradict their function for accommodation any sensory setae, which would have more or less uniform width. Opening at the apex of spine was likely occupied by non-mineralised tissue and has a pressure-receptor function.

Broda \& Zatoń (2017) described a possible sensory system preserved in the cuticle of thylacocephalan Concavicaris sp. from the Upper Devonian of Poland. Sensory system consists of circular depression located in characteristic polygons forming the carapace exterior ornamentation except the ventral periphery of the carapace. Other sensory organs of Concavicaris sp. occur exclusively along margins of carapace. They observed belts of tubular structures penetrating the cuticle but not reaching its surface along the ventrocaudal part and the dorsum of the carapace. These belts are connected in a rostral and caudal area. In summary, the presence of spines extending from the cuticle does not contradict the thylacocephalan origin of the Bohemian cuticle fragment.

Plate III Scanning electron micrographs of exterior and interior of arthropod cuticle fragment; all come from the lower part of the Choteč Formation, in the Basal Choteč Event interval, bed No. 12-top.

1, 8 - Fragment of cuticle, probably external surface of carapace, with more arched periphery (top) and thinner flatter pitted part (below); note largely opened spines - in the left top corner, blind spine in the middle, and three couples of smaller spines at the top; detail of these small spines (8) with solitary spines behind, PCZCU 2401. 2, 3 - Fragment of cuticle, likely internal surface of carapace, showing polygonal wrinkles and weak traces of segmentation in the concave part of the carapace, and a solitary spine in its lower part; note a detailed view of interior with complex structural braces of the carapace (3), PCZCU 2399. 4-7, 9 - Fragment showing thin double wall of cuticle (4), interior of carapace with irregularly folded and bumpy surface (5-7), and detail of surface showing polygonal bumps with a rugged surface that probably represent epithelial cell moulds (9), PCZCU 2400. Scale bars are in micrometers. 
Unlike thylacocephalans, the phyllocarid carapaces lack spines along the ventral margin of carapace (Chlupáč 1963, 1970). There are small uniform spinules aligned at the posterior margin of the carapace of Caryocaris wrighti Salter, 1863 which represent only short extensions from the margin of carapace, lacking tubular character of spines observed in the cuticle fragment from the Choteč Limestone.

Thylacocephalans are not known from the Basal Choteč Event interval in the Barrandian area, only Concavicaris desiderata (Barrande, 1872) was described from the underlying Daleje-Třebotov Formation. Phyllocarid affinity of this species was suggested by Chlupáč (1963) but Vannier et al. (2006) reassigned this species to thylacocephalans. According Chlupáč (1963) only three specimens were observed in the lower part of Daleje Shale within the Nowakia cancellata Zone (upper Emsian). The Daleje Shale is characterised by soft calcareous shale with micritic limestone intercalations and nodules. The member is a result of the Daleje Event explained by sea level rise of probably a global scale (House 1985, Chlupáč \& Kukal 1986, 1988). Fossil content of the Daleje Shale is dominated by planktonic and nectonic biota, with very abundant dacryoconarids, nautiloids and diverse benthic fauna. The Daleje Event and the Basal Choteč Event most likely had similar control on marine biota, and thus the presence of thylacocephalid Concavicaris in sediments of the Basal Choteč Event would be anticipated.

\section{Ultrastructure of cuticular fragments}

The innermost layer of the cuticle of Recent crustaceans is the membranous layer (Roer \& Dillaman 1984). It consists of chitin and protein and is in contact with the hypodermis. The hypodermis is heterogeneous, made up of more cell types which are responsible for the formation of the cuticle.

Polygonal bumps observed on the internal wall of cuticle fragments likely represent the epithelial cell moulds. However, their size between 0.7 to $1.5 \mu \mathrm{m}$ is smaller than common size rank of epithelial cells known in other fossil invertebrates including the ostracods (Olempska 2012). Winrow \& Sutton (2012) reviewed the size of epithelial cells in fossil organophosphatic brachiopod mantle epithelium. They observed variability ranging from 5 to $30 \mu \mathrm{m}$, with a mean size about $15 \mu \mathrm{m}$. The same size of epithelian cells was recognized in early Cambrian acrotretid brachiopods (Zhang et al. 2016). In antipatharian corals from the Lower Ordovician, the sizes of epithelian cells vary from 6 to $9 \mu \mathrm{m}$ (Baliński et al. 2012). Note that the mean size of epithelial cells is 9 to $17 \mu \mathrm{m}$ in human lens and about $30 \mu \mathrm{m}$ in skin cells (Brown \& Bron 1987). The inner surface of an anorganic endocuticle in Recent crustaceans shows the crystal organization with 200 to $400 \mathrm{~nm}$ wide spherolites (Roer \& Dillaman 1984). Similarly sized spherolites are visible at the surface of bumps in the cuticular fragments from the Choteč Limestone.

\section{CONCLUSION}

Fragments of phosphatic cuticle, which was extracted from limestone of the Basal Choteč Event interval display some remarkable structures: hollow annulated spines of variable size, some with an opening at the top, different structures of inner and outer size of two-layered carapace, and polygonal bump-like structure preserved on the internal wall of the cuticle, which is interpreted as epithelial cell moulds despite its smaller size compared with a mean size of epithelial cell in other invertebrates. Biological affinity of the cuticle fragments is unclear, although their arthropod origin in not contested. Thylacocephalan affinity is discussed, also due to the occurrence of Cancavicaris in nearby stratigraphic horizons with similar fossils. Phyllocarid origin of cuticles is improbable.

Bloom of prasinophytes, eutrophic and oxygen depleted environment indicated by biological attributes of associated fossils, and a sedimentation in a deeper sea are typical for dark limestones of the Basal Choteč Event. These environmental conditions are consistent with suggested requirements of the Palaeozoic thylacocephalans (Vannier et al. 2006) and indirectly confirm assignment of the observed fragments to this arthropod clade.

\section{ACKNOWLEDGMENTS}

I greatly thank to Martina Kočová-Veselská and Stanislava Vodrážková for critical reviews, comments, corrections and suggestions which significantly enhance the manuscript. Grants from the University of West Bohemia for 2019 supported the work. 


\section{REFERENCES}

Baliński, A., Sun, Y. \& Dzik, J. 2012. 470-Millionyear-old black corals from China. Naturwissenschaften 99, 645-653.

Barrande, J. 1872. Systême silurien du centre de la Bohême. Supplement au vol. I. Trilobites, Crustacés divers et Poissons. Prague-Paris. 34 pls.

Berkyová, S. 2009. Lower-Middle Devonian (upper Emsian-Eifelian, serotinus-kockelianus zones) conodont faunas from the Prague Basin, the Czech Republic. Bulletin of Geosciences 84(4), 667-686.

Berkyová, S., Frýda, J. \& Suttner, T.J. 2009. Lower - Middle conodont faunas from Prague Basin. Berichte der Geologischen Bundesanstalt 79, 9-10.

Bischoff, G. \& Ziegler, W. 1957. Die Conodontenchronologie des Mitteldevons und des tiefsten Oberdevons. Abhandlungen des Hessischen Landesamtes für Bodenforschung 22, 1-136.

Braig, F., Haug, J.T., Schädel, M. \& Haug, C. 2019. A new thylacocephalan crustacean from the Upper Jurassic lithographic limestones of southern Germany and the diversity of Thylacocephala. Paleodiversity 12(1), 69-87.

Brocke, R., Fatka, O., Lindemann, R.H., Schindler, E. \& Ver Straeten, C.A. 2016. Palynology, dacryoconarids and the lower Eifelian (Middle Devonian) Basal Choteč Event: case studies from the Prague and Appalachian basins, 123169. In Becker, R.T., Königshof, P. \& Brett, C.E. (eds) Devonian Climate, Sea Level and Evolutionary Events. Geological Society, London, Special Publications 423, 123-169.

Brown, N. A. \& Bron, A.J. 1987. An estimate of the human lens epithelial cell size in vivo. Experimental Eye Research 44(6), 899-906.

Briggs, D.E.G., Liu, H.P., McKay, R.M. \& Witzke, B.J. 2018. The Winneshiek biota: exceptionally well-preserved fossils in a Middle Ordovician impact crater. Journal of the Geological Society 175, 865-874.

Broda, K. \& Zatoń, M. 2017. A set of possible sensory system preserved in cuticle of Late Devonian thylacocephalan arthropods from Poland. Historical Biology 29, 1045-1055.

Buggisch, W. \& Mann, U. 2004. Carbon isotope stratigraphy of Lochkovian to Eifelian limestones from the Devonian of central and south- ern Europe. International Journal of Earth Sciences 93, 521-541.

Chlupáč, I. 1957. Stratigraficko-paleontologický výzkum břidlic dalejských a vápenců hlubočepských ve středočeském devonu. Věstník Ústředního ústavu geologického 32, 248-258.

Chlupáč, I. 1959. Facial development and biostratigraphy of Daleje Shales and Hlubočepy Limestones (Eifelian) in the Devonian of Central Bohemia. Sborník Ústředního ústavu geologického, oddíl geologický 24, 446-511.

Chlupáč , I. 1963. Phyllocarid crustaceans from the Silurian and Devonian of Czechoslovakia. Palaeontology 6(1), 97-118.

Chlupáč, I. 1970. Phyllocarid crustaceans of the Bohemian Ordovician. Sbornik geologických věd, Paleontologie 12, 41-77.

Chlupáč, I. 1998. Devonian, 101-133. In Chlupáč, I., Havlíček, V., Kříž, J., Kukal, Z. \& Štorch, P. Palaeozoic of the Barrandian (Cambrian to Devonian). Czech Geological Survey, Prague.

Chlupáč, I. \& Kukal, Z. 1986. Reflection of possible global Devonian events in the Barrandian area, Č.S.S.R. In Walliser, O.H. (ed.) Lecture Note in Earth Sciences, Global Bio-events, 169179.

Chlupáč, I. \& Kukal, Z. 1988. Possible global events and the stratigraphy of the Palaeozoic of the Barrandian (Cambrian-Middle Devonian, Czechoslovakia). Sborník geologických věd, Geologie 43, 83-146.

Chlupáč, I., Lukeš, P. \& Zikmundová, J. 1979. The Lower-Middle Devonian boundary beds in the Barrandian area, Czechoslovakia. Geologica et Palaeontologica 13, 125-156.

Collette, J.H. \& Hagadorn, J.W. 2010. The early evolution of phyllocarid arthropods: phylogeny and systematics of Cambrian-Devonian archaeostracans. Journal of Paleontology 84, 795-820.

Dames, W. 1886. Ueber einige Crustaceen aus den Kreideablagerungen des Libanon. Zeitschrift der Deutschen Geologischen Gesellschaft 38(3), 551576.

Forchielli, A. \& Pervesler, P. 2013. Phosphatic cuticule in Thylacocephalans: a taphonomic case study of Austriocaris (Arthropoda, Thylacocephala) from the Fossil-Lagerstätte Polzberg (Reingraben Shales, Carnian, Upper Triassic, Lower Austria). Austrian Journal of Earth Sciences 106, 46-61. 
Havlíček, V. 1977. Minute Devonian brachiopods (Notanopliidae, Leptostrophiida) in Bohemia. Věstník Ústředního ústavu geologického 52, 299-302.

Havlíček, V. \& Racheboeuf, P.R. 1979. Chonetacea (Brachiopodes) du Silurien et du Dévonien de Bohême (Tchécoslovaquie). Annales de Paléontologie (Invertébrés) 65, 69-138.

House, M.R. 1985. Correlation of mid-palaeozoic ammonoid evolutionary events with global sedimentary perturbations. Nature 313, 17-22.

Klapper, G., Ziegler, W. \& Mashkova, T. 1978. Conodonts and correlation of Lower-Middle Devonian boundary beds in the Barrandian area of Czechoslovakia. Geologica et Palaeontologica $12,103-116$.

Koptíková, L. 2011. Precise position of the Basal Choteč event and evolution of sedimentary environments near the Lower-Middle Devonian boundary: The magnetic susceptibility, gammaray spectrometric, lithological, and geochemical record of the Prague Synform (Czech Republic). Palaeogeography, Palaeoclimatology, Palaeoecology 304(1-2), 96-112.

Lamsdell, J.C., Briggs, D.E.G., Liu, H.P.,Witzke, B.J. \& McKay, R.M. 2015a. A new Ordovician arthropod from the Winneshiek Lagerstätte of Iowa (USA) reveals the ground plan of eurypterids and chasmataspidids. The Science of Nature 102, 1-8.

Lamsdell, J.C., Briggs, D.E.G., Liu, H.P., Witzke, B.J. \& McKay, R.M. 2015b. The oldest described eurypterid: a giant Middle Ordovician (Darriwilian) megalograptid from the Winneshiek Lagerstätte of Iowa. BMC Evolutionary Biology 15, $1-31$.

Langenstrassen, F. 1972. Fazies und Stratigraphie der Eifel-Stufe im östlichen Sauerland. Göttinger Arbeiten zur Geologie und Paläontologie 12, $106 \mathrm{p}$.

Mergl, M. 2001. Lingulate brachiopods of the Silurian and Devonian of the Barrandian. Acta Musei nationalis Pragae, Series B - Historia Naturalis 57, 1-49.

Mergl, M. \& Vodrážková, S. 2012. Emsian-Eifelian lingulate brachiopods from the Daleje-Třebotov Formation (Třebotov and Suchomasty limestones) and the Choteč Formation (Choteč and Acanthopyge limestones from the Prague Basin; the Czech Republic). Bulletin of Geosciences 87(2), 315-332.

Olempska, E. 2012. Morphology and affinities of Eridostracina: Palaeozoic ostracods with moult retention. Hydrobiologia 688, 139-165.

Pinna,G., Arduini, P., Pesarini,C. \& Teruzzi, G. 1982. Thylacocephala: una nuova classe di crustacei fossili. Atti della Societá Italiana di Scienze Naturali e del Museo Civico di Storia Naturale di Milano 123, 469-482.

Roemer, F.A. 1843. Die Versteinerungen des Harzgebirges. Verlag der Hahn'schen Hofbuchhandlung. Hannover. 40 pp.

Roer, R. \& Dillaman, R. 1984. The structure and calcification of the crustacean cuticle. American Zoology 24, 893-909.

Rolfe, W.D.L. 1983. Form and function in Thylacocephala, Conchyliocarida and Concavicarida (?Crustacea): a problem of interpretation. Transactions of the Royal Society of Edinburgh $76,391-399$.

Salter, J.W. 1863. Note on the Skiddaw Slate fossils. Quarterly Journal of the Geological Society London 19, 135-140.

Schram, F.R., Hof, C.H.J. \& Steeman, F.A. 1999. Thylacocephala (Arthropoda: Crustacea?) from the Cretaceous of Lebanon and implications for thylacocephalan systematics. Palaeontology 42, 769-797.

Secretan, S. 1985. Conchyliocarida, a class of fossil crustaceans: relationship to Malacostraca and postulated behaviour. Transactions of the Royal Society of Edinburgh 76, 381-389.

Svoboda, J. \& Prantl, F. 1947. O stratigrafii a tektonice staršího paleozoika v okolí Třebotova. Sborník Státního geologického ústavu 14, 281314.

Vannier, J., Chen, J.Y., Huang, D.Y., Charbonnier, S. \& Wang, X.Q. 2006. The Early Cambrian origin of thylacocephalan arthropods. Acta Palaeontologica Polonica 51, 201-214.

Winrow, P. \& Sutton, M.D. 2012. Epithelial cell moulds in acrotretoid brachiopods. Historical Biology 24(5), 557-565.

Zhang, Z., Zhang, Z. \& Wang, H. 2016. Epithelial cell moulds preserved in the earliest acrotretid brachiopods from the Cambrian (Series 2) of the Three Gorges area, China. GFF 138(4), 455466. 